\title{
How The Implications Of Change In The Taxation System Foreign Citizens In Indonesia Based On Law No.11 Of 2020 About Creation Work
}

\author{
Mangerbang Simanullang, Michael Alexander Nata \\ Business administration focus on tax management, Institut STIAMI, Jakarta, Indonesia \\ DOI: 10.29322/IJSRP.11.02.2021.p11039 \\ http://dx.doi.org/10.29322/IJSRP.11.02.2021.p11039
}

\begin{abstract}
The Government of the Unitary State of the Republic of Indonesia has a significant and long-term goal, namely that by 2045 it can get out of the middle-class income trap. Indonesia is a constitutional state based on Pancasila and the 1945 Constitution of the Republic of Indonesia to create the people's welfare and prosperity. This prosperity goal can achieve through fair and equitable tax collection. Tax collection is imposed on all citizens in Indonesia, including foreign nationals. In determining the tax subject, Indonesia does not look at citizenship to make it possible for foreign citizens to become domestic tax subjects. Domestic tax subjects' status for foreign citizens will have an impact on taxation with the concept of worldwide income to the income they have. The worldwide income taxation system for foreign citizens optimizes state revenue and affects the emergence of juridical double taxation. This impact will attempt to overcome by the formation of Law Republic of Indonesia No. 11 of 2020 concerning work copyright. This provision changes foreign nationals' taxation who have domestic taxpayers' status to no more extended use of the worldwide income system. Foreign nationals who can use this taxation system must meet several stipulated terms and conditions. This new taxation system will have an impact on both foreign and Indonesian citizens. Indonesia's impact is mainly related to the potential for tax revenue, so it is essential to ensure that the requirements given are by the objectives to realized from this change in taxation policy.
\end{abstract}

Index Terms - Big Goals, Taxation System Change, Worldwide Income.

\section{INTRODUCTION}

Currently, the business world globally has experienced increasingly dynamic development. Various developments have been influenced primarily by rapid advances in technology and science. Various countries have their responses and responses to the existing developments. The Indonesian Government itself has big and long-term goals in 2045. That goal is to become a nation capable of escaping the middle-class income trap. The Government hopes that Indonesia can later become a developed country with an estimated income of around Three hundred twenty million rupiahs per capita per year or Rp. 27 million per month and has a Gross Domestic Product (GDP) of 7 trillion US dollars. To accomplish these goals, the Government must build superior human resources supported by a conducive political and economic ecosystem.

The Unitary State of the Republic of Indonesia is a constitutional state based on Pancasila and the 1945 Constitution of the Republic of Indonesia, which upholds citizens' rights and obligations and creates a prosperous, just, and prosperous Indonesian society. To accomplish people's welfare and prosperity source of income is needed to support this. One source of income that currently plays a vital role in Indonesia is the taxation sector. Taxation itself is a manifestation of obligations in the state, which is a means of financing the state for national development. In-Law Number 17 of 2003 concerning State Finance, it is stated that state revenue is all revenue originating from tax revenues, non-tax state revenues, and grant receipts from within and outside the country. Taxes can also be defined as compulsory contributions to the state-owned by individuals or entities and are coercive based on the law without receiving direct compensation and used for state needs for the most excellent welfare of the people. [1]

One way to collect tax in Indonesia is base on fairness and equality for all tax subjects on the income earned. The tax subjects in Indonesia include Indonesian citizens as well as foreign citizens. About determining the tax subject, a foreign citizen can become a domestic tax subject in Indonesia as long as he meets the specified criteria. The Indonesian Government adheres to the imposition of taxes on all income for domestic taxpayers [2]. This provision will also apply to foreign nationals when they are subject to domestic tax. In this condition, the impact will be on foreign citizens who also have income in their home country. The Indonesian Government wants to change this policy in order to attract foreign citizens to enter Indonesia. The change in taxation policy for foreign citizens was then stated in the Republic of Indonesia Law number 11 of 2020 concerning work creation.

Changes in taxation policies on foreign entities such as those carried out by Indonesia are regular and occur in other countries. Tax changes or reforms have different objectives depending on each country. In this case, Indonesia needs to pay attention to many things in following the trend of changes in existing taxation policies because it is not necessarily by Indonesia's conditions and characteristics. Concerning tax reform in several countries, one of the forms is to provide concessions to create better economic growth. In terms of providing such concessions, the current trend in Organization for Economic Co-operation and 
Development (OECD) countries is to change the taxation system from worldwide to territory [3]. The main target of this change is, of course, foreign entities, especially foreign citizens. Changes in taxation policies for foreign nationals made by Indonesia include changes in the system worldwide to territorial, accompanied by several unique requirements. This policy can provide legal certainty regarding tax obligations for foreign citizens to attract those with unique expertise to work in Indonesia. [4]

In connection with the above, it is essential to understand the implications of policy changes related to foreign nationals' taxation in Indonesia through the Republic of Indonesia Law No.11 of 2020. This research will focus on the form of change that occurred and the potential that will result from the change. The taxation policy is specifically for Indonesia.

\section{RESEARCH METHODOLOGY}

This study uses a qualitative method that aims to obtain a complete and comprehensive understanding of the actual problems that occur in society. In solving existing problems, this research uses a case study approach. The case study focuses on the implications of the change in taxation policy for foreign citizens with the Republic of Indonesia Law number 11 of 2020 . The implications will show in terms of changes that occur. The potential generated, both positive and negative, the data used in this study using primary and secondary legal material data. Primary legal material data is in the form of authoritative or authoritative data. This data gets in the form of legislation, official records, minutes on the formulation of legislation, and judges' decisions. Meanwhile, secondary legal material data is in the form of legal publications that are not official documents. Publications on law include books, legal dictionaries, legal journals, and commentary on court decisions. [5]

\section{BASIS OF THEORY}

\subsection{Principles of Foreign Income Taxation}

Two main principles of taxation are known to be related to income held abroad, namely: [6]

\section{a. Domicile}

Income will be taxed in the country of domicile, whether obtained from within the country or abroad. Countries that use the domicile principle will generally use the worldwide income principle.

\section{a. Territorial}

Income will be taxed on income earned (activities to generate income) in a country's territory (territory). In this case, the tax only applies to income earned within the country's territory, so that income obtained from outside the country is not subject to tax.

Indonesia is a country that uses a mixed principle. Domestic taxpayers will use the domicile principle, while foreign taxpayers will use the territorial principle. Taxation based on the principle of domicile on domestic taxpayers will impact the worldwide income principle. The principle of worldwide income is a principle whereby income tax based on income received in the source country and the residence country.

In determining taxpayer status, Indonesia does not use the citizenship criteria in determining the status of domestic taxpayers. According to Indonesia's income tax provisions, every person or entity must become a taxpayer if it meets subjective and objective requirements. Subjective requirements related to the provisions as a subject by Indonesian income tax law. The objective requirements relate to the income received or earned and the obligation to deduct and collect the applicable income tax provisions.

\subsection{Multiple Taxation}

Multiple taxations are a condition in which an income will tax twice, or the same tax object will tax twice in this case. In practice, there are two types of double taxation, namely: [7]

\section{a. Juridical Multiple Taxation}

Juridical Multiple Taxation is the taxation of the same income by two different countries in a certain period. In this condition, the domicile country will impose taxes on tax subjects who obtain income from another country, the source country. On the other hand, income earned from the source country will also tax in that country.

\section{b. Economical Multiple Taxation}

Economical Multiple Taxation Represents taxation of the same income earned by two different tax subjects in the same period. One form of this condition is related to dividend taxation. In this condition, the operating profit should have been subject to income tax at the company level. However, on the same income when distributed as dividends, it will be subject to income tax again on the individual side as the recipient. 
The occurrence of double taxes will cause injustice, which in the long run will hinder transactions and economic traffic between countries. Each country will endeavor to minimize double taxation effects, considering that sometimes it cannot be avoided.

\subsection{Double Tax Avoidance Agreement (P3B) / Tax Treaty in Indonesian tax law}

Double Tax Avoidance Agreement (P3B) or tax treaty is a tax treaty between 2 countries that regulates the distribution of taxation rights on income earned or received by residents of one or both countries that agreed. Tax treaty policies can divide into two main issues: major and minor. On a significant issue, this will differ depending on the background and tax regulations. For categorized issues categorized as major, it is often challenging to compromise than the minor ones. The tax treaty's function is basically to avoid double taxation. Through this, taxation rights will divide between the domicile and the source country. This concept then makes a tax treaty, often referred to as "distributive rules." Tax treaty has a position above domestic law, but if there are new taxation rights that are not under domestic law, it can do not implemented. Tax treaties here cannot expand taxation rights that are not under a country's domestic law. Benefits earned in connection with being an employee by a foreign taxpayer will be subject to income tax through the withholding of $20 \%$. However, this provision may not necessarily apply if the employee is a taxpayer from a country with a tax treaty agreement with Indonesia. The $20 \%$ income tax can only use if certain conditions are required. This taxation shows a relationship between the tax treaty and domestic provisions, in this case, the income tax law. The tax treaty's position here is to limit Indonesia's income tax law [8].

\section{DISCUSSION}

\subsection{The Taxation System for Foreign Citizens is by the Law of the Republic of Indonesia No 11 of 2020}

Foreign nationals are tax subjects as long as they meet the requirements as stipulated in the tax laws in force in Indonesia. The requirements related to foreign nationals' taxation refer to several things, including the period of stay (time test). The length of time a foreign citizen lives in Indonesia will determine the type and rate of taxes that will impose in connection with his / her income. In the current era of globalization, every country will be more open to people from abroad who enter their country, including Indonesia. Foreign citizens who come and work in Indonesia will be subject to the tax laws applicable in Indonesia. Provisions regarding the determination of a tax subject's status are regulated in articles two paragraphs 3 and 4 of the Law of the Republic of Indonesia No. 36 of 2008 concerning income tax. This provision explained that the subject of domestic tax is an individual who resides in Indonesia or has been in Indonesia for more than 183 (one hundred and eighty-three) days within a period of 12 (twelve) and has the intention to reside in Indonesia. Foreign tax subjects do not reside in Indonesia, individuals in Indonesia for no more than 183 (one hundred and eighty-three) days within 12 (twelve) months, and entities that are not established and do not have a domicile. In Indonesia, who run a business or carry out activities through a permanent establishment in Indonesia [8]. This provision shows that the determination of a tax subject in Indonesia does not look at a person's citizenship status. When the above conditions meet, foreign citizens can also become domestic tax subjects for tax purposes.

This status as a domestic tax subject will make a foreign citizen fully comply with Indonesia's taxation regulations about his / her income. Indonesia applying taxation to the income of its citizen adopts a worldwide income system. This worldwide income taxation system implies that domestic tax subjects will tax on income obtained from within or outside the country or, in this case, is income worldwide. The principle of worldwide income taxation is also clearly stated in article 4 of Law of the Republic of Indonesia No. 36 of 2008 concerning income tax, which states that the object of income tax is any additional economic capability received or obtained by a taxpayer, whether originating from Indonesia or from outside Indonesia. , which can be used for consumption or to increase the wealth of the Taxpayer concerned, under whatever name and form. For Indonesia, this taxation system has negative and positive impacts. The positive impact, which was immediately fell for Indonesia, is the optimization of tax revenue. A worldwide income taxation system will make the country not lose its domestic tax subjects' potential taxation, especially its citizens. Current tax revenue still has a significant contribution to the Indonesian economy, considering that the contribution of tax revenue to Indonesia's state budget is still substantial. This fact makes the worldwide income tax system profitable for the country to optimize revenue from the tax sector.

For foreign nationals, the impact of the worldwide income system will fell when applied. Foreign nationals, especially those whose status has become a domestic tax subject, will also be bound by this provision. The tax rate imposed on foreigners will indeed be fairer, namely with a progressive rate depending on foreign income. This taxation will be different if the foreign citizen's status is still subject to foreign taxes while in Indonesia. If the status is still a foreign taxpayer, the tax imposition system will refer to article 26 in the Indonesian income tax law with a rate of $20 \%$ regardless of the amount of income one has. This rate will change when the country of the foreign national concerned has a tax treaty with Indonesia. In such a case, the income that is subject to tax will also include income originating from within and outside the country or a worldwide income system, such as an Indonesian citizen who is a domestic tax subject. This taxation system has a significant impact on foreign citizens who have a large income in their home country.

On the one hand, this worldwide income taxation system does optimize state revenues. On the other hand, worldwide income taxation can also affect the emergence of juridical double taxation. Juridical double taxation by definition is a condition where there is the taxation of the same income by two different countries in a certain period. For example, in this case, a foreign citizen who comes from a country with a worldwide income taxation system will be subject to tax in the source country and domicile on the income they have. The effect of this juridical double taxation will become even more complicated when both the source 
country and the domicile country of the foreign citizens concerned both adhere to the worldwide income tax system and become domestic tax subjects in 2 different countries. In this condition, what happens is that the source country will calculate taxes using a worldwide income mechanism. In this case, the domicile country will also apply taxation on the same income to be multiple taxations. If this is not observed correctly and observed, it will hurt the economy in general. Indonesia will become less attractive to foreign citizens, even though foreign citizens' presence can also positively impact knowledge transfer.

The taxation system of foreign income adopted by a country other than worldwide income is territorial.

The selection of the taxation system adopted by each country will adjust to the objectives to achieve. One of the considerations used to choose a taxation system is related to economic factors. A country that is trying to attract investment from investors will sometimes choose to use the territorial system. The consideration is that this system will only impose taxes obtained (activities to generate income) in the territory (territory) of a country. In this case, the only tax imposed is on income earned within the country's territory, so that income obtained from outside the country is not subject to tax. In selecting the most profitable system, it is essential to consider whether it is according to a country's objectives and economic considerations. Indonesia, which is currently still developing its economy, is trying to create a conducive climate to attract investment and foreign parties to enter and contribute to existing development plans.

To achieve these desired economic goals, the Republic of Indonesia Law No. 11 of 2020 on work copyright was formed. The content and content of the law covers many things, one of which is taxation for foreign citizens. Taxation of foreign citizens in the Law of the Republic of Indonesia No.11 of 2020 is explained in article 4 paragraphs (1a), (1b), (1c) in the Income Tax cluster. In this provision, it stipulated that Excepted from the provisions as referred to in paragraph. (1), foreign citizens who have become domestic tax subjects are subject to Income Tax only on income received or obtained from Indonesia provided that: (a) have specific expertise and ( b) is valid for 4 (four) tax years counting since becoming a resident tax subject. Includes the meaning of income received or obtained from Indonesia as referred to in paragraph (1a) in the form of income received or obtained by a foreign citizen connected with a job, service, or activity in Indonesia under whatever name and form paid outside Indonesia. The provisions as intended in paragraph (1a) do not apply to foreign citizens who take advantage of the Double Taxation Avoidance Agreement between the Government of Indonesia and the Government of the partner country or partner jurisdiction of the Double Taxation Avoidance Agreement where foreign citizens earn income from outside Indonesia ”[10].

This new taxation provision will allow a foreign citizen to tax in Indonesia the only specific originating in Indonesia so that it can be said to have overridden the worldwide income system previously adopted. This kind of taxation model can also say that Indonesia has implemented a territorial taxation system on foreign nationals' income in Indonesia. Foreign nationals who can use this taxation system must meet several requirements and conditions as regulated in the Law of the Republic of Indonesia No. 11 of 2020. These provisions include, among other things, that foreign citizens must have expertise so that if this is true, it will work has a positive impact on Indonesia in the long term. The change in this provision will make foreign nationals subject to domestic taxation avoid large amounts of taxation, as was when the worldwide income regime imposed on them. Another essential requirement for applying this taxation system to foreign nationals is the prohibition of using the Double Tax Avoidance Agreement clause between the Government of Indonesia and the Government of the partner country. Of course, this is not admit considering that this taxation system's use will create overlaps in applying taxation provisions. This requirement and various other requirements show that the imposition of taxes on foreign nationals cannot fully be said to adhere to the territoriality principle, given there are certain conditions that must meet. When the conditions are not meet, the taxation system will still use the old scheme to return to worldwide income. Therefore, the taxation scheme for foreign citizens after enacting Law No. 11 of 2020 is more appropriate if it is said to adhere to the "Semi Territorial" system.

\subsection{What are the implications of changes in the taxation of foreign citizens in Indonesia}

The Law of the Republic of Indonesia No.11 of 2020 has made significant changes to the existing taxation provisions in Indonesia. One of the changes in the taxation of foreign citizens. This provision can also be said to be one of the solutions to global tax problems in Indonesia. International tax will talk about the taxation of foreigners or foreign companies' income from Indonesia and income received by Indonesian people or companies from abroad. Issues and problems surrounding international taxation are becoming increasingly common due to the increasing flow of investment, trade, and mobility of human resources that no longer recognize national borders. The impacts problems on the tax side because each country has its regulations for taxation rules. The impact of this is mainly on the subject and object of foreign taxes [11]. International tax will be base on domestic taxation provisions that apply to domestic taxpayers who derive income from Indonesia. Apart from domestic regulations, international taxes are base on tax treaties and global tax practices.

According to the Law of the Republic of Indonesia No. 11 of 2020, the new taxation system will positively impact foreign citizens, where they will avoid enormous tax burdens due to the application of worldwide income. If it will have a positive impact on foreign citizens, then the opposite is true for Indonesia. This taxation system will certainly decrease the potential for tax revenue from foreign citizens' income. However, even though this creates potential tax loss from the implementation of this taxation system, in the long term, the trade-off that can accomplish is the availability of quality human resources in Indonesia. This taxation system will attract foreign citizens to work and live in Indonesia so that the transfer of technology and knowledge can be optimized. Changes in tax policy are sometimes necessary to achieve an important goal, especially when linked to economic considerations. However, it is also essential that the achievement of these goals does not result in considerable losses. As this change in the taxation system, for Indonesia, this is a potential tax loss because it is more of an incentive for foreign 
citizens. In implementing this policy, Indonesia needs to be very careful and careful to be effective. In conditions where this policy cannot implement appropriately, there will be a risk that there will be perceived violations of the Indonesian Government's principle of justice in tax collection. This assumption is mainly related to the Government's attitude, which will be considered more supportive of foreign workers than those from within the country. The justice principle must always be carried out in the tax collection process to carry out generally and evenly. Fair and equitable tax collection is something that must always be analyzed so that its implementation does not cause resistance from the community. The practice of fair tax collection is not easy to do because the criteria or standards of justice are often varied [12].

In applying the new taxation system for foreign citizens, it is necessary to ensure that the requirements give really must be appropriate. If the goal is to develop human resources, there should also be provisions regarding the foreign citizen's country of origin. Foreign nationals who come from developed countries with advanced economic growth indexes should priority using this taxation policy than those from countries with an economic index equal to or even below Indonesia. The potential tax loss predicted to occur from changes in the taxation system will be resolved when the main objective is to accomplish. In the short term, Indonesia seems to be providing incentives and subsidies to foreign citizens because they are independent of worldwide income requirements. However, it will produce higher quality human resources from transferring knowledge and technology in the long term.

Changes in taxation policies for foreign citizens are a very natural thing in the international world. Changes in taxation policies aim to make every country have a competitive advantage in the international world. Many studies show that these changes in taxation policy directed at the taxation of individuals. Taxation policies for individuals, mostly foreign nationals, are not always associated with lowering lower tax rates. Many studies show that low tax rates are not always the main draw for foreign nationals for several reasons. First, the actual tax burden determines by a combination of the tax rate and tax base. Second, there is not much evidence to suggest that the movement or mobility of workers is fully affected by the income tax rate. [13].

One case study related to policy changes on foreign income taxation can see in the United States. The United States is a country that shares worldwide income, just like Indonesia, wherein 2010, it made changes to its taxation policy on foreign income. This policy allows for benefits from crediting the taxes paid abroad so that foreign tax subjects, especially multinational companies, will enjoy the benefits. The existence of this provision will make income from abroad not taxable as long as not repatriated to the United States. At first glance, this seems very profitable for multinational companies with businesses in the United States. However, it is different for companies with parents in the United States and subsidiaries outside the United States. In this case, it will create complexity for the company because it will provide its complexity in terms of investment strategy so that the cost of doing business increases [14]. This case should illustrate that policy changes still have to pay attention to various aspects.

On the one hand, the United States' policy tries to provide convenience to foreign tax subjects. However, on the other hand, it can create complexity and difficulties for companies that have domestic parents. Every policy that is implemented needs always to evaluate and Indonesia is no exception. Important that the implementation of new taxation policies for foreign nationals needs to be evaluated and adjusted according to it does not contribute negatively to the economy in the long term.

\section{CONCLUSION}

Based on the explanations that have presented in the previous chapters, it can conclude that the following are:

1. Law of the Republic of Indonesia No. 11 of 2020 concerning Job Creation has made changes to the taxation system for foreign citizens to no longer fully Worldwide Income.

2. The taxation system for foreign nationals based on territorial principles, but there are requirements and restrictions. It is accurate, described as "Semi-Territorial."

3. Changes in the taxation of foreign nationals according to Law No. 11 of 2020 can cause tax loss in the short term. However, it aims to support development in the long term because of the transfer of knowledge and expertise from "quality" foreign nationals.

4. Changes in the taxation system for foreign nationals need to evaluate, especially requirements. It would be better if foreigners from a country with an economic index higher than Indonesia would be preferred.

5. Changes in foreign nationals' taxation policy for economic considerations are as common as what has happened in the United States. However, it is necessary always to evaluate the impact and benefits.

\section{REFERENCES}

[1] Law No.16 of 2009 concerning General Provisions and Tax Procedures 
[2] Directorate General of Taxes of the Republic of Indonesia. Principle of tax imposition. https://www.pajak.go.id/id/asaspengenaan-pajak

[3] Fleming, J.C., Peroni, R. J., \& Shay, S. E. Some Perspectives from The United States on The World Wide Taxation vs. Territorial Taxation Debate. Journal Of The Australasian Tax Teachers Association, vol 35, 2008, 35-86.

[4] Ministry of Finance of the Republic of Indonesia. Academic Paper on the Draft Law on Taxation Provisions and Facilities for Strengthening the Economy. 2019

[5] Marzuki, P.M. Legal Research. The tenth print. Prenamedia Group. Jakarta. 2015.

[6] Kurniawan, A.M. Tax Treaty. First print. Bee Media, Indonesia. Jakarta. 2012.

[7] Darussalam, Hutagaol, J., Septriadi, D. Concepts and Applications of International Taxation. First print. PT. The International Tax Dimension. Jakarta. 2010

[8] Rachmanto, S. Agreement on Avoidance of Double Taxes: A Study of Indonesian Policy. Four Salemba. Jakarta. 2011

[9] Law of the Republic of Indonesia No. 36 of 2008 on Income Tax.

[10] Law of the Republic of Indonesia No 11 of 2020 concerning Job Creation.

[11] Wisanggeni, I. International Tax (Practical Overview). First Edition. Mitra Wacana Media. Jakarta. 2019.

[12] Burton, R. The Study of Taxation in the Context of Welfare and Justice. Mitra Wacana Media. Jakarta. 2014

[13] Sommerhalder, R.A. Dutch Tax Simplification: Unique in an International Setting ?. Journal of Economic Psychology, vol 13, 1992, 597-607.

[14] Escoffier, S.D. New International Tax Provisions. Journal of Corporate Accounting \& Finance, Vol 22, No 2, 2011,75 - 78. 